\title{
The Effect of the Harmony between Organizational Culture and Values on Job Satisfaction
}

\author{
Erkan Taşkıran ${ }^{1}$, Canan $_{\text {Çetin }}{ }^{2}$, Ata Özdemirci ${ }^{2}$, Baki Aksu ${ }^{3}$, Meri İstoriti ${ }^{4}$ \\ ${ }^{1}$ School of Tourism Administration and Hotel Management, Düzce University, Düzce, Turkey \\ ${ }^{2}$ Faculty of Business Administration, Marmara University, Istanbul, Turkey \\ ${ }^{3}$ Vocational School of Logistics, Beykoz University, Istanbul, Turkey \\ ${ }^{4}$ Liv Hospital, Istanbul, Turkey \\ Correspondence: Erkan Taşkıran, School of Tourism Administration and Hotel Management, Düzce University, \\ Osmaniye Mahallesi, Atatürk Caddesi, No.221 Akçakoca, 81650, Düzce, Turkey.
}

Received: March 13, 2017

doi:10.5539/ibr.v10n5p133

\author{
Accepted: April 19, 2017 \\ Online Published: April 24, 2017 \\ URL: https://doi.org/10.5539/ibr.v10n5p133
}

\begin{abstract}
In this study, the effect of the harmony between organizational culture and values on job satisfaction is examined. Hierarchical regression analysis was applied to the data, which was obtained from the study conducted on 181 employees working in a private hospital in Istanbul. The result of the analysis shows that value-culture variation in which employees will have the highest job satisfaction is the traditionalist/conservative values-clan culture. The second most successful value-culture variation on job satisfaction is the impulsive/hedonistic values-adhocracy culture. In other words, it is predicted that job satisfaction will be high when an employee with traditionalist/conservative values works in an organization where clan culture is important, and an employee with impulsive/hedonistic values works in an organization where adhocracy culture is important. The most negative impacts on job satisfaction are impulsive/hedonistic values-clan culture and precautionary values-market culture. In other words, it can be said that an employee with impulsive/hedonistic values will be unhappy in clan culture, and an employee with precautionary values will be unhappy in market culture.
\end{abstract}

Keywords: organizational culture, values, job satisfaction

\section{Introduction}

Schein (1984) defines organizational culture as the pattern of basic assumptions that a given group has invented, discovered, or developed in learning to cope with its problems of external adaptation and internal integration and have worked well enough to be considered valid to be taught to new members to perceive, think, and feel in relation to those problems. The establishment of a strong organizational culture is critical in two respects. First, with the help of an organizational culture, employees have an opportunity to develop business relationships, adopt procedures and rules, internalize values and norms, and form collective behavior patterns. Second, organizational culture has direct or indirect influences on the structure, strategy and management approach of an organization. For instance, the culture of an organization influences information about marketing strategies and the messages of the organization (Ahamed \& Mahmood, 2015). Therefore, there are important relationships between the success of the management of a business and the functioning of the organizational cultures. The rules that determine the behavior of the employees within the organization, the organizational structure, and the accepted organizational principles also shape the functioning of the organization. The power to control the degree of compliance of employees within the organizational culture is especially influential, since it will determine the quality of the relationships among the employees. Also, it will determine the effectiveness of the organization's operation and the extent to which the rules will be adopted by the executives (Erdoğan, 2007). Organizational culture is one of the most difficult concepts to understand and define. This is because organizational culture covers the values, expectations, implicit assumptions, and legacy that are part of the organization. While organizational culture is not recognized by most employees, it provides a sense of identity to employees and an unspoken guidance on how to get along within the organization. (O'Riordan, 2015). It is very important for organizations to create a strong organizational culture in order to protect their market position. In this context, the organization should develop an organizational culture that will create support, and focus on 
continuous development. The presence of a strong organizational culture will also ensure the permanent retainment of employees (Habib et al., 2014).

Since the first studies on the concept of values were completed, the concept has been widely used, especially in the field of organizational behavior and behavioral sciences, as well as in branches of science such as sociology, psychology, anthropology and social psychology. Values are often examined in order to identify cultural groups, community, people, and change that occurs over time. Values are also used to explain the motivational basics of attitudes and behaviors (Schwatrz, 2012). In this context, it is increasingly important to investigate the relationships between the values of individuals, the level at which culture affects the organizations in which they work, and the relationship and harmony between the variables and issues such as job satisfaction, commitment and motivation. Job satisfaction, one of the most important factors in terms of the analysis of behaviors within the framework of business management, includes positive feelings and attitudes that an individual has about his or her work (Riggio, 2014). The general attitudes of the employees regarding their work, and the work environment, are an indication of their job satisfaction levels.

On the one hand, job satisfaction is of great importance in terms of having a favorable effect of the experiences in the organization, and on the individual, while also affecting the emotional needs and value judgments of the individual employees (Erdoğan, 2007). Hence, managers should be aware that employees, particularly those with low job satisfaction, may tend to avoid work, and that they frequently make an effort to leave their job and begin working for another company (Türk, 2007). It is especially important to note that a strong organizational culture is expected to have a positive effect on job satisfaction. Robbins and Hutcheson emphasize that job satisfaction is the result of the existence of an organizational culture (Biswas, 2015: 16). In general, the information available in the literature supports the conclusion that the harmony between values of employee and the organization leads to the development of varied attitudes towards the organizations in which the employees serve (Amos \& Weathington, 2008).

In this context, specifically, the main objective of this study is to examine the effect of the harmony between organizational culture and values on job satisfaction. This paper provides empirical evidence regarding the relationships among organizational culture, values and job satisfaction in a de veloping country setting, Turkey. The results can be used as a reference for organizations to recognize which individual values are appropriate for increasing the job satisfaction. This study also draws attention to which variations among values and organizational culture is coherent for job satisfaction levels of employees. Within this perspective, this paper draws a route for organizations to constitute such a work environment encouraging the harmony between organizational culture and values to enhance the job satisfaction levels of employees.

\section{Literature Review and Hypotheses}

\subsection{Organizational Culture}

The concept of culture began to pass the forefront in the field of management science in the late 1960s (Fleury, 2009). As a whole, the concept of a culture created by individuals coming together in accordance with certain principles can be primarily considered as protection of the individual against the physical environment. In this context, cultures are the beliefs, values and judgments of individuals that constitute a society. It is important for a manager of an organization to be familiar with these elements. Within this frame, for the manager of an organization, culture can be defined as the set of beliefs, values, customs and outcomes of other interpersonal relationships created by certain human communities affecting the way of the institution works, and other activities of the institution. On the other hand, organizational culture refers to the ways the organization conducts its business Therefore, organizational culture is one of the important distinguishing factors of an organization (Erdoğan, 2007). Numerous studies in a wide array of contexts have established the importance of organizational culture in determining success or failure of firms (Naqshbandi, et al., 2015b). Muafi (2009, p.106) has defined organizational culture as values, ideology, reputation, philosophy, symbols, customs, and the norms affecting organizational performance. In this context, corporate culture can be spread among employees in different forms, including ceremonies, stories, physical elements that are symbolic, and language, which are the most effective elements (Robbins \& Judge, 2013). These elements will be briefly discussed. Stories are short narratives shared among employees and adapted from real events to inform others, especially new employees, about the organization. Physical symbols are the element that evokes something that distinguishes one organization from another. Physical symbols can be stronger than other elements, especially because they attract attention to the obvious theme. For example, Mother, a small advertising agency based in London, has no doors within the entire premises, except for the toilets. Therefore, this physical element symbolizes the cultural values of the organization, such as open communication, cooperation, creativity and equality (Daft, 2015). Ceremonies cover 
some stereotypical activities that express and strengthen the organization's key values. For example, organizations such as Wal-Mart, IBM, and Pricewaterhouse Cooper use corporate songs as a ceremonial element of organizational culture. Finally, language represents an element that can help employees to integrate with organizational culture, acknowledge their acceptance of the culture, and protect it (Robbins \& Judge, 2014).

There have been prominent culture studies over the last 30 years in the study of organizational behavior, especially in terms of improving organizational effectiveness and gaining perspective on the optimal use of human resources (Landekic, et al., 2015). In this context, organizational culture is classified by different researchers in different ways (Çavuşoğlu \& Köse, 2016). The "Competing Values Framework", developed by Cameron and Quinn, is the most emphasis among these classifications. Cameron and Quinn, according to their model, classify four different cultures as clan culture, market culture, hierarchy culture and adhocracy culture (Bogdanowicz, 2014):

- Clan Culture: In this culture, it is important to take care of the employees, and to ensure that they have what they need to be satisfied and productive. In this context, the main focus of clan culture is to meet the needs of employees to achieve high performance. In this context, employee involvement and expectations of rapid change due to the external environment gains importance. Employee involvement creates a sense of responsibility, and increases their commitment to the organization. For example, Wegmans, a large supermarket chain, is an example of the clan culture because it invests heavily in employee development and support programs, such as scholarships to both full-time and part-time employees, paying good salaries, and sending employees to workshops and seminars. Employees are encouraged to take the initiative in dealing with customer issues and being creative (Daft, 2015).

- Market culture: This culture type focuses on a result-oriented business environment. Leaders within the organization are competitive, tough and demanding. The emphasis on winning keeps the organization together and long-term expectations, aggressiveness, making competitive moves, achieving goals and objectives are the elements of this culture. Organizational success is measured by market share and leadership in the market (Bogdanowicz, 2014).

- Hierarchy culture: This type of culture tends to be bureaucratic and is observed in organizations that reduce working creativity (Nam \& Kim, 2016). Within this context, organizations with a hierarchy culture achieve goals through formal rules and close supervision rather than through shared values (Naqshbandi, Kaur \& Ma, 2015a). Pre-determined procedures assign what to do and what not to do within the organization. The focal point of this culture is to keep the organization functioning smoothly. The most important feature is enforcing formal rules and policies which keep the organization together. This kind of culture is especially prevalent in the management of public institutions (Öz, Kaya \& Çiftçi, 2015). Today, most administrators move away from this type of culture, because of the need for greater flexibility. However, Pasific Edge, as an example, has successfully implemented hierarchy culture principles to ensure that all projects are on time and on budget. (Daft, 2015).

- Adhocracy Culture: This culture type focuses on an entrepreneurial, flexible and creative business environment. There is an organic structure in which organizational status and positions are ignored, or considered only temporarily. Adhocracy culture is characterized by - far from being centralized - there is an emphasis on individual initiative and risk; this encourages creativity and the freedom to be flexible (Erdem, 2007). Google is one of the best examples of this type of organizational culture, highlighting values, creativity, individual initiative, experience, risk-taking and entrepreneurship. In addition, organizations such as companies in the marketing, electronics and cosmetics sectors that have to move fast to satisfy the customers can be evaluated within the scope of this culture type (Daft, 2015).

The four different categories in the Competitive Value Model described above relate to the harmony between cultural values, strategy, structure and environment. Each of them can be successful, depending on the needs of the external environment, and the focus of the organizational strategy (Daft, 2015).

\subsection{Values}

Different countries around the world and the varied societies within these countries may have similar or divergent values, depending on their cultures. The concept of value, one of the main sources of life and actions, is also of great importance in terms of the individuals which form the society. As indi viduals organize their lives according to the values which they have adopted, they measure the values they have by assessing and judging the different situations they face as a source of basic perception (Şişman, 2002). The concept of value is defined by different authors in different ways. Value is the sum of beliefs underlying the intellectual and behavioral processes that influence the behavior that can lead to a desired end-of-life situation, and that influences a person 
in different situations (Connor \& Becker, 2002; Özgener, 2004). Another definition of value is the beliefs and convictions that guide the ideals, preferences, decisions, and behaviors that are an essential part of the individual's work and daily life. (Cavanagh \& McGovern, 1998, p.1). According to Hofstede (2001, p. 5), value is defined as the tendency to prefer a particular situation in relation to others. Schwartz (1992) opines that values are desirable, trans-situational goals that serve as guiding principles in the life of a person or other social entity (Çalışkur, 2014). According to Schwartz, values represent subjective beliefs that are based on emotions and are related to the goals that individuals want to achieve. Schwartz suggests that values are indicative of individual norms and behaviors about what is right and what is wrong. Hence, values emphasize the characteristics underlying individual behaviors, while also helping individuals to make assessments in certain events or situations. In this context, it can be said that the concept of values is individualistic, guiding and the importance that one places on values, varies from person to person (Özcan, 2012).

The theory of basic individual values de veloped by Schwartz is one of the leading theories in the field in the last 20-30 years (Lilleoja and Saris, 2014). Schwartz refers to the existence of three different universal needs in the context of his model (Schwartz, 1994). Accordingly, the universal needs are (Newton and Mazur, 2016): (1) biological organisms, (2) requisites of coordinated social interaction, and (3) survival and welfare needs of groups. Based on these three universal needs, Schwartz has defined 10 value types. These values and definitions are given in Table 1 below.

Table 1. Schwartz's Value Types and Their Definitions

\begin{tabular}{ll}
\hline Value Type & Definition \\
\hline Benevolence & Preserving and enhancing the welfare of those with whom one is in frequent personal contact. \\
Universalism & Understanding, appreciation, tolerance, and protection for the welfare of all people and for nature. \\
Self-direction & Independent thought and action--choosing, creating, exploring. \\
Stimulation & Excitement, novelty, and challenge in life. \\
Hedonism & Pleasure or sensuous gratification for oneself. \\
Achievement & Personal success through demonstrating competence according to social standards. \\
Power & Social status and prestige, control or dominance over people and resources. \\
Security & Safety, harmony, and stability of society, of relationships, and of self. \\
Conformity & Restraint of actions, inclinations, and impulses likely to upset or harm others and violate social \\
& expectations or norms. \\
Tradition & Respect, commitment, and acceptance of the customs and ideas that one's culture or religion provides.
\end{tabular}

Source: Schwartz, S. H. (2012). "An Overview of the Schwartz Theory of Basic Values". Online Readings in Psychology and Culture, 2 (1), pp.5-7.

In his theory of basic individual values, Schwartz classifies the 10 motivational values shown in Table 1 as values that reflect individual, collective, and mixed interests (both individual and collective) within a circle. According to this, motivational values such as power, success, hedonism, anxiety and self-direction are within the area of individual interest; on the opposite side, motivational values such as benevolence, tradition and adaptive values reflect the common interest area. As the universalism and security motivational values between these two groups can be included in both groups, they constitute the group of mixed motivational values and the limit of individual and collective value spaces (Devrani, 2010).

\subsection{Job Satisfaction}

The job satisfaction concept is the most important variable that can be considered as an output in the context of the input-process-output models. In this context, job satisfaction has found a large work area particularly in the field of organizational psychology (Körner, et al., 2015). Job satisfaction is an attitude that reflects the assessments of the individual's job and job experience for a certain period (Schermerhorn, et.al., 2010). According to the most well-known and recognized definition by Locke (1976, p.1304), job satisfaction refers to a pleasurable or positive emotional state resulting from the appraisal of one's job or job experiences. In other words, job satisfaction can result when the characteristics of the job are assessed, and the individual develops positive feelings about his or her job. There are three important dimensions of job satisfaction: values, the levels of importance placed on these values, and perceptions. Values cover the subjective needs that are in the mind of the individual. In this context, job satisfaction is considered as a function of the values that the individual has developed, consciously or unconsciously. Second, the existence of these values does not mean that they are the same for every individual. For example, while job security is most important for one employee, another employee prefers a job that offers travel on business trips, rather than job security. According to these values, job satisfaction differs according to employees. On the other hand, perception is related to how the values and the present situation are seen by individual employees. Reactions differ according to the perception of indivudal employees (Wagner \& Hollenback, 2010). In this context, by evaluating the job satisfaction, employee adds both 
thoughts and opinions and feelings about the work (Saari \& Judge, 2004).

\subsection{The Effect of the Harmony between Organizational Culture and Individual Values on Job Satisfaction}

The underlying reasons for individual attitudes, perceptions and behaviors can be explained through the concept of values. Therefore, by learning about an individual's value system, you can also have an opinion about why that individual behaves in a certain way, and what affects him or her. At this point, the harmony between individual values and the organization is coming into prominence. For example, a lack of harmony is a strong possibility between an individual who attaches great importance to independence, imagination, creativity, or freedom, and an organization that closely monitors employee compliance, within its organizational context. The opposite situation will greatly improve organizational alignment and harmony. While managers tend to appreciate and reward employees for adapting to the organization's culture, employees tend to get job satisfaction when they perceive that they are a good fit. Therefore, the organization should keep in mind that while it is necessary to search for candidates who are qualified to do the job, it is also important to assess a candidate's value system, to determine if these values are compatible with those of the organization (Robbins \& Judge, 2013). In this context, organizational culture is considered to be the most effective factor in demonstrating the desirable and expected behaviors that will enable employees to achieve more, and produce more positive organizational outputs (Kaoa, Tsaur \& Wub, 2016). Some studies stated that culture encourages employees to be more innovative (Naqshbandi, Kaur \& Ma, 2015a; Naqshbandi \& Kaur, 2011). The more an employee understands and grasps shared values within the organization, the fewer the disruptions to the creation of a coherent organizational culture (Cekuls, 2015). Job satisfaction is a function of the values that an employee gains from his job, consciously or unconsciously (Wagner \& Hollenback, 2010). Organizational culture is as effective an influence on job satisfaction as experience, personality and job-related duties (Robbins \& Judge, 2013).

When the studies on the variables within the scope of the job are examined, it can be seen that there are meaningful relationships between these variables. For example, Lund (2003) examined the effects on job satisfaction of culture types described by Cameron and Quinn. According to the results of this research, it was found that there is a positive relationship between clan and adhocracy cultures and job satisfaction, and a negative relationship between market and hierarchy cultures and job satisfaction. Tsai (2011) finds that job satisfaction levels increase in organizations with a strong organizational culture. As a result of research conducted on 530 nurses working in public and private hospitals, Jacobs and Roodt (2008) found that organizational culture has a significant effect on job satisfaction. Amos and Weathington (2008) determined that the harmony between employee and organizational values has a positive effect on job satisfaction. Nystrom (1993) found that employees in the health sector have a high level of job satisfaction, if the organization in which they work has a strong organizational culture. In another study, Tovey and Adams (1999) stated that organizational culture is one of the primary factors in job satisfaction. İşcan and Timuroğlu (2007) stated that clan and adhocracia culture types have a positive effect on job satisfaction; hierarchy and market cultures are inversely related to job satisfaction. Rızaoğlu and Ayyıldız (2008) examined the closeness of the relationship between organizational culture and job satisfaction, and determined that cultural power, service quality and customer value dimensions are the most important factors affecting employee job satisfaction. Bellou (2010) suggested that job satisfaction is low in organizations with aggressive organizational cultures, while it is high in organizations that offer equal pay, and opportunities for personal development, It is also high in organizations where there is a general passion for work and a strong image. In addition, Din and Ghetany (2016), Şendoğdu, Özata and Çiftçi (2014), Habib, Aslam, Hussian, Yasmeen and Ibrahim (2014), Vukonjanski and Nikolic (2013), MacIntosh and Doherty (2010), Johnson and Mclynte (1998), Tzeng, Ketefian and Redman (2002) have reached the conclusion that organizational culture influences job satisfaction. Some studies (Olasupa, 2011) did not find a correlation between organizational culture and job satisfaction. Odom, Boxx, and Dunn (1990) stated that hierarchical culture types, one of the organizational culture types, do not promote employee job satisfaction.

It is stated in related literature that the harmony between individual values and organizational values will affect the employees' business behaviors. In this context, when considering individual values for the individual and organizational culture for the organization, an increase of the harmony between the individual and the organization makes positive contributions to the behavior and outputs (e.g. job satisfaction) of the individual in the business environment. Integrative harmony among the culture, values, targets and norms of the organization, and the personality, values, goals and rules of individuals can affect the organizational outcomes (K1lıç, 2010). When the studies dealing with the relationship between individual values and job satisfaction are evaluated, Y1lmaz and Dilmaç (2011) examined the effects of teachers' values on job satisfaction and showed that among teachers, job satisfaction was significantly correlated with the sub items of the individual values, such as power, achievement, hedonism, arousal, self-control, universality, charity, tradition and security. Another result of the 
research is the determination that teachers' job satisfactions significantly predict their personal values.

Employees working in a strong organizational culture act in accordance with shared values and norms that support both individual and organizational goals and objectives. In this context, employees will work in harmony to successfully perform the tasks assigned to them, ensure adequate job performance, and develop job satisfaction (Tsai, 2011). Similarly, Kane-Urrabazo (2006) notes that a healthy and strong organizational culture is an important influence in creating a satisfying work environment. Therefore, with this study, in the context of the effect of the harmony between the individual and the organization on organizational outcomes, the harmony between individual values and organizational culture and their impact on job satisfaction, the following hypotheses have been developed to be tested.

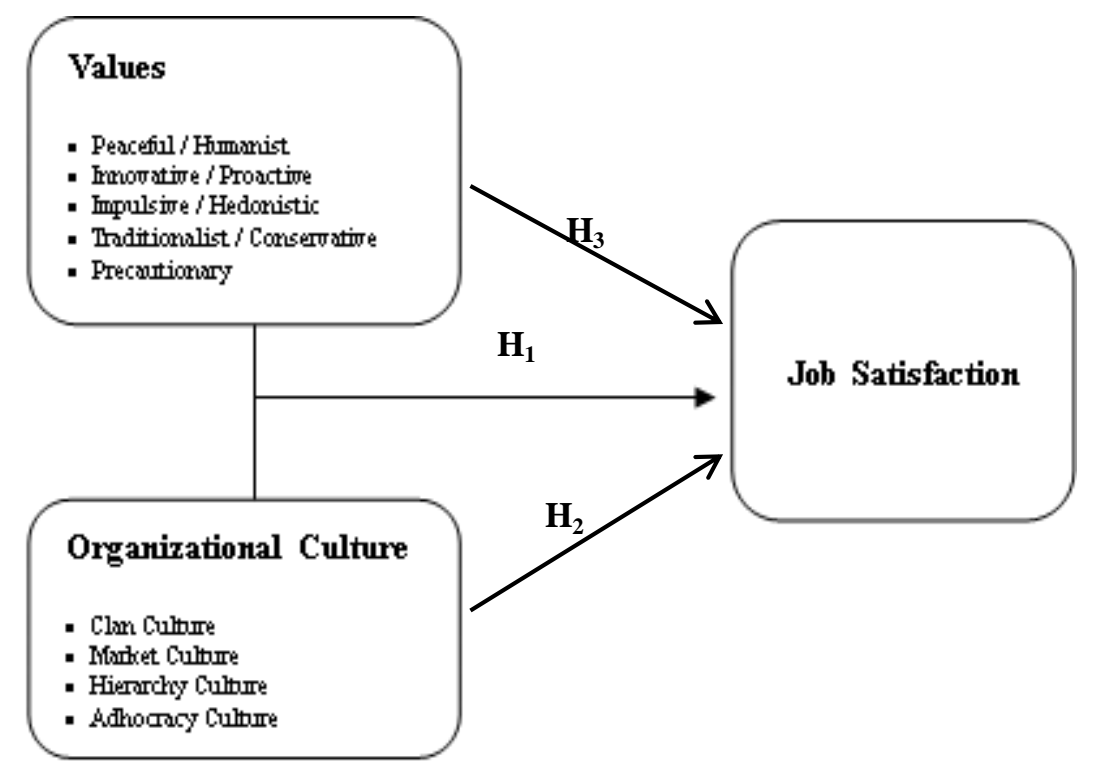

Figure 1. Model of the Study

Hypothesis $1\left(\mathbf{H}_{\mathbf{1}}\right)$ : The harmony between organizational culture and individual values has a significant effect on job satisfaction.

Hypothesis $2\left(\mathbf{H}_{2}\right)$ : Types of organizational culture have a significant effect on job satisfaction.

Hypothesis $3\left(\mathbf{H}_{\mathbf{3}}\right)$ : Employees' values have a significant effect on job satisfaction.

In first phase of the analysis of the research, the effects of restructured personal values and organizational cultures on job satisfaction were examined separately, after factor and reliability analysis. Then the effect of a combination of 20 different individual values - organizational culture combinations on job satisfaction - was examined, so that the most compatible and the most incompatible combinations were determined.

\section{Methodology}

\subsection{Sampling and Data Collection Method}

The research was conducted on Liv Hospital's employees in Istanbul. During the period of the research, there were 545 employees in the hospital at all levels of employment. Questionnaires were distributed to all employees through full census sampling, and 181 questionnaires that were properly completed were collected. Analysis was based on the data obtained from the questionnaires.

The demographic characteristics of the participants that were gathered from the questionnaire are presented in Table 2. Accordingly, the majority of participants were female $(67.4 \%)$ and under 30 years of age $(69.06 \%)$. Considering the health sector in which the research was conducted, the high number of women and young employees can be accepted as normal for this sector. Regarding education level, most of the participants $(91.2 \%$ in total) had a bachelor's degree, an associate's degree, or had been to high school. Of the total, $30,9 \%$ had a bachelor's degree, $48,1 \%$ had an associate's degree, and 12,2\% had been to high school.

In terms of income variable, the majority of the employees who completed the questionnaire, $81.8 \%$ of the sample, had an income between $1300 \mathrm{TL}$ and $3000 \mathrm{TL}$. Regarding seniority in firm, the majority of the participants were found to have 1-5 years of seniority (66.9\%). Lastly, in terms of professional seniority of the 
participants, it was shown that, again, the majority of the employees (44.2\%) had been on the job between 1-5 years.

Table 2. Demographical Characteristics of the Participants

\begin{tabular}{|c|c|c|c|}
\hline & & $\mathbf{f}$ & $\%$ \\
\hline \multicolumn{4}{|l|}{$\operatorname{Sex}$} \\
\hline & Female & 122 & 67,4 \\
\hline & Male & 59 & 32,6 \\
\hline \multicolumn{4}{|l|}{ Age } \\
\hline & Under 24 & 57 & 31,49 \\
\hline & $24-29$ & 68 & 37,57 \\
\hline & $30-35$ & 32 & 17,68 \\
\hline & $36-41$ & 20 & 11,05 \\
\hline & $42-48$ & 1 & 0,55 \\
\hline & Above 48 & 3 & 1,66 \\
\hline \multicolumn{4}{|c|}{ Education Level } \\
\hline & High School & 22 & 12,2 \\
\hline & Associate's Degree & 87 & 48,1 \\
\hline & Bachelor's Degree & 56 & 30,9 \\
\hline & Master's Degree & 12 & 6,6 \\
\hline & Doctorate & 4 & 2,2 \\
\hline \multicolumn{4}{|c|}{ Income } \\
\hline & Between $1300 \mathrm{TL}-3000 \mathrm{TL}$ & 148 & 81,8 \\
\hline & Between $3001 \mathrm{TL}-6000 \mathrm{TL}$ & 30 & 16,6 \\
\hline & Between $6001 \mathrm{TL}-10000 \mathrm{TL}$ & 1 &, 6 \\
\hline & More than $10000 \mathrm{TL}$ & 2 & 1,1 \\
\hline \multicolumn{4}{|c|}{ Seniority in Firm } \\
\hline & Less than 1 year & 55 & 30,4 \\
\hline & $1-5$ years & 121 & 66,9 \\
\hline & $6-10$ years & 4 & 2,2 \\
\hline & More than 16 years & 1 &, 6 \\
\hline \multicolumn{4}{|c|}{ Professional Seniority } \\
\hline & Less than 1 year & 24 & 13,3 \\
\hline & $1-5$ years & 80 & 44,2 \\
\hline & $6-10$ years & 39 & 21,5 \\
\hline & $11-15$ years & 15 & 8,3 \\
\hline & More than 16 years & 23 & 12,7 \\
\hline
\end{tabular}

$N=181$

\subsection{Scales}

The organizational culture, values and job satisfaction variables that were considered in the scope of this study were evaluated using three different scales (Table 3).

Table 3. Scales Used in the Study

\begin{tabular}{llc}
\hline Scale & Developed By & $\begin{array}{c}\text { Number } \\
\text { Ite ms }\end{array}$ \\
\hline Values & Knoppen ve Saris (2009) & 40 \\
Organizational Culture & Cameron ve Quinn (2011) & 24 \\
Job Satisfaction & MSQ, Martins ve Proença (2011) & 6 \\
\hline
\end{tabular}

3.2.1 Value Scale

The Schwartz Value Survey developed by Schwartz (1992) was used to measure values (Schwartz, 2017). Years after the scale was de veloped it was differentiated due to the development of preferences for some of the values, and changes caused by the way or arrangement of the response scale. The 40 -item version adapted from the Schwartz Value Survey by Knoppen and Saris (2009) was used in this study. The scale allows questions to be answered on a 6-point Likert basis from Strongly Disagree (1) to Strongly Agree (6).

\subsubsection{Organizational Culture Scale}

To measure organizational culture, a variable of this study, a scale developed by Cameron and Quinn (2011) was used. This scale was preferred in this study since it is comprehensively common and easier to understand. It consists of a total of 24 questions that identifies four types of organizational culture, namely clan, adhocracy, market and hierarchy. Participants who completed the questionnaire were asked to respond to questions on a 6-point Likert basis from Strongly Disagree (1) to Strongly Agree (6). 


\subsubsection{Job Satisfaction Scale}

To measure the level of job satisfaction of the participants, a 6-question scale developed by Martins and Proença (2011) on MSQ for hospital employees and covered the internal dimensions of job satisfaction was used. The scale allows questions to be answered on a 6-point Likert basis from Strongly Disagree (1) to Strongly Agree (6).

\subsection{Factor and Reliability Analysis}

For each dimension of the scale, exploratory factor analysis was applied. Each factor passed through the KMO and Bartlett tests and the Anti Image analysis. Items that were below the value of the sampling adequacy of 0.50, the only one remaining under the factor, and factor loadings too close to each other were excluded from the evaluation.

Five factors that emerged from the factor analysis on the value scale were given terms of "Peaceful / Humanist"; "Innovative / Proactive", "Impulsive / Hedonistic", "Traditionalist / Conservative" and " Precautionary".

Table 4. Results of Factor and Reliability Analysis

\section{Values}

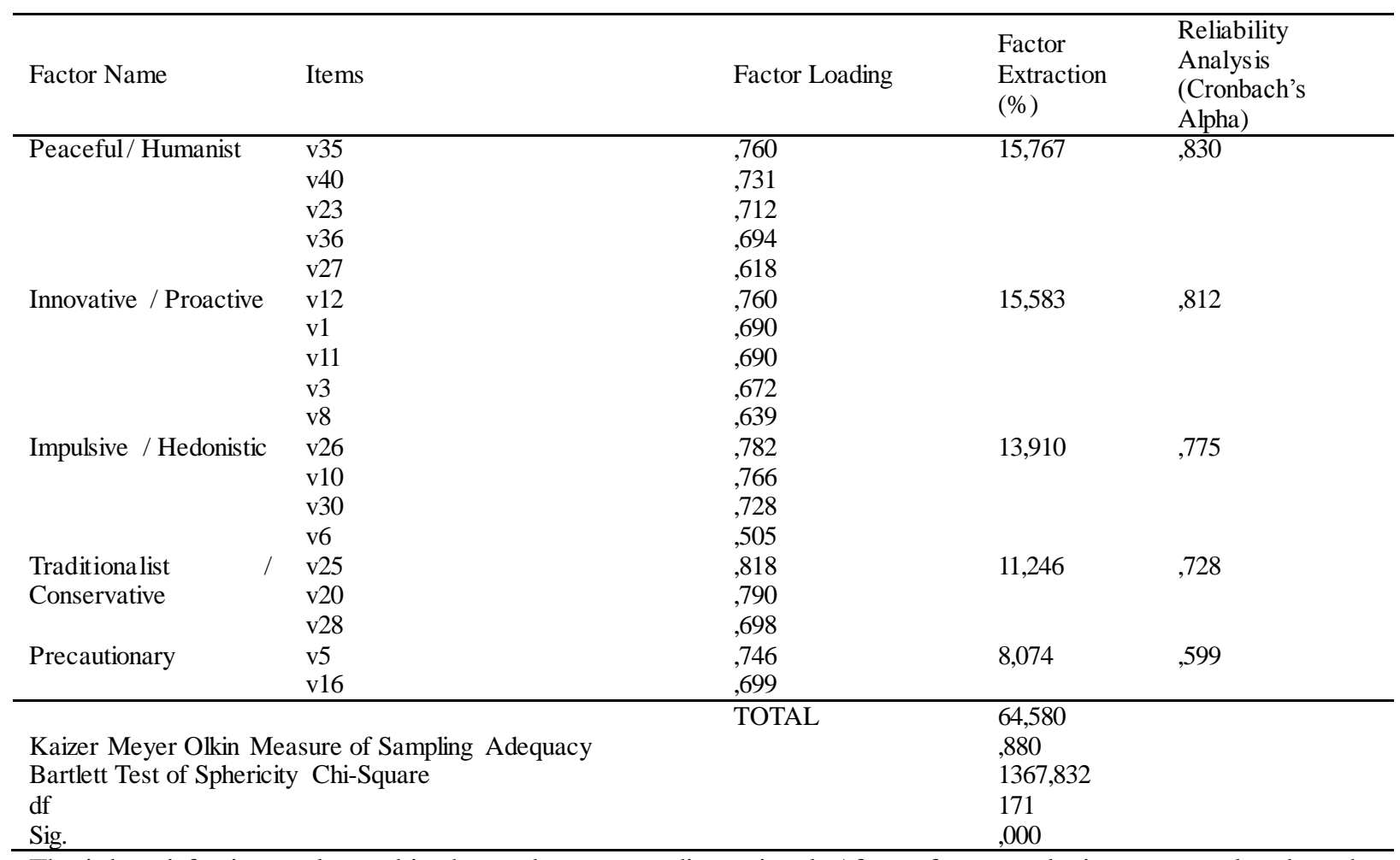

The job satisfaction scale used in the study was one dimensional. After a factor analysis was completed on the satisfaction scale using 6 questions, 3 questions were removed due to low factor loadings. There was a satisfaction level with a high reliability covering 3 questions.

\section{Job Satisfaction}

\begin{tabular}{|c|c|c|c|c|}
\hline Factor Name & Items & Factor Loading & $\begin{array}{l}\text { Factor } \\
\text { Extraction } \\
(\%)\end{array}$ & $\begin{array}{l}\text { Reliability } \\
\text { Analysis } \\
\text { (Cronbach's } \\
\text { Alpha) }\end{array}$ \\
\hline Satisfaction & $\begin{array}{l}\text { sat2 } \\
\text { sat4 } \\
\text { sat1 }\end{array}$ & $\begin{array}{l}921 \\
, 893 \\
, 893\end{array}$ & 81.458 & 886 \\
\hline \multicolumn{2}{|c|}{$\begin{array}{l}\text { Kaizer Meyer Olkin Measure of Sampling Adequacy } \\
\text { Bartlett Test of Sphericity Chi-Square } \\
\text { df } \\
\text { Sig. }\end{array}$} & TOTAL & \multicolumn{2}{|l|}{$\begin{array}{l}81.458 \\
, 738 \\
301,584 \\
3 \\
, 000\end{array}$} \\
\hline
\end{tabular}

In the factor analysis on the organizational culture scale, four factors appeared as if they were originally in the scale: "Clan Culture", "Market Culture", "Hierarchy Culture" and "Adhocracy Culture". 


\section{Organi zational Culture}

\begin{tabular}{|c|c|c|c|c|}
\hline Factor Name & Items & Factor Loading & $\begin{array}{l}\text { Factor } \\
\text { Extraction } \\
(\%)\end{array}$ & $\begin{array}{l}\text { Reliability } \\
\text { Analysis } \\
\text { (Cronbach's } \\
\text { Alpha) }\end{array}$ \\
\hline \multirow[t]{6}{*}{ Clan Culture } & oc4 & ,840 & 25,945 & 950 \\
\hline & oc5 & 803 & & \\
\hline & oc3 & ,789 & & \\
\hline & oc2 & ,783 & & \\
\hline & oc6 & ,766 & & \\
\hline & oc1 1 & 723 & & \\
\hline \multirow[t]{6}{*}{ Market Culture } & oc18 & 815 & 18,917 & 883 \\
\hline & oc17 & 788 & & \\
\hline & oc16 & ,726 & & \\
\hline & oc15 & 694 & & \\
\hline & oc14 & 681 & & \\
\hline & oc13 &, 554 & & \\
\hline \multirow[t]{4}{*}{ Hierarchy Culture } & oc22 & ,772 & 15,046 & ,900 \\
\hline & oc23 &, 731 & & \\
\hline & oc21 &, 723 & & \\
\hline & oc24 &, 720 & & \\
\hline \multirow[t]{5}{*}{ Adhocracy Culture } & oc 10 & ,716 & 15,000 & ,917 \\
\hline & oc8 & ,701 & & \\
\hline & oc 11 & 653 & & \\
\hline & oc7 & 653 & & \\
\hline & oc 12 & ,569 & & \\
\hline & & TOTAL & 74,908 & \\
\hline \multicolumn{3}{|c|}{ Kaizer Meyer Olkin Measure of Sampling Adequacy } & ,937 & \\
\hline \multicolumn{2}{|c|}{ Bartlett Test of Sphericity Chi-Square } & & 3348,745 & \\
\hline \multicolumn{2}{|c|}{$\begin{array}{l}\text { df } \\
\text { Sio }\end{array}$} & & 210 & \\
\hline \multicolumn{2}{|l|}{ Sig. } & & 0,000 & \\
\hline
\end{tabular}

\section{Findings}

\subsection{Correlation Analysis}

The correlations between factors, factor averages and standard deviations are shown in Table 5. The most accepted among the values is the innovative / proactive, the least accepted is the traditionalist / conservative. The organization concerned has been largely associated with hierarchy and market culture. The satisfaction level is not very high. There are significant relationships between both independent variables and dependent and independent variables. More reliable interpretations will be made after the regression analysis.

Table 5. Correlation Analysis

\begin{tabular}{|c|c|c|c|c|c|c|c|c|c|c|c|c|c|}
\hline & & Ort & SS & 1 & 2 & 3 & 4 & 5 & 6 & 7 & 8 & 9 & 10 \\
\hline 1.Peaceful / Humanist & & 5,07 & 0,80 & 1 & & & & & & & & & \\
\hline 2.Innovative / Proactive & & 5,22 & 0,80 & $.556^{* *}$ & 1 & & & & & & & & \\
\hline 3.Impulsive / Hedonistic & & 4,75 & 0,95 & $.498^{* * *}$ & $.569^{* *}$ & 1 & & & & & & & \\
\hline 4.Traditionalist & I & 4,37 & 1,09 & $.369^{* *}$ & $.301^{* *}$ & $.317^{* *}$ & 1 & & & & & & \\
\hline 5.Precautionary & & 4,96 & 1,02 & $.501^{* *}$ & $.422^{* *}$ & $.300^{* *}$ & $.284^{* *}$ & 1 & & & & & \\
\hline 6.Clan Culture & & 3,71 & 1,35 & $.194^{* \pi *}$ & $.170^{\pi}$ & $.202^{* \pi}$ & $.376^{+3+4}$ & $.215^{* \pi}$ & 1 & & & & \\
\hline 7.Market Culture & & 4,27 & 1,11 & $.300^{* * *}$ & $.320^{* *}$ & $.252^{* *}$ & $.280^{* *}$ & $.169^{*}$ & $.565^{* *}$ & 1 & & & \\
\hline 8.Hierarchy Culture & & 4,30 & 1,18 & $.396^{* *}$ & $.363^{* *}$ & $.340^{* * *}$ & $.400^{* *}$ & $.297^{* *}$ & $.650^{* * *}$ & $.692^{* *}$ & 1 & & \\
\hline 9.Adhocracy Culture & & 3,79 & 1,21 & $.225^{* * \pi}$ & ,121 & $.188^{*}$ & $.379^{* *}$ & $.227^{* *}$ & $.798^{* *}$ & $.602^{* * \pi}$ & $.657^{* *}$ & 1 & \\
\hline 10.Job Satisfaction & & 3,64 & 1,15 & $.180^{\circ}$ &,- 008 & ,095 & .246 & $.210^{*}$ & $.651^{*}$ & .452 & $.531 \%$ & .660 & 1 \\
\hline
\end{tabular}

Sample Size $(\mathrm{N})=181 * \mathrm{p}<0,05, * * \mathrm{p}<0,01$

\subsection{Hierarchical Regression Analysis for $H_{1}$ Hypothesis}

The hierarchical regression analysis for the $\mathrm{H}_{1}$ hypothesis is shown in Table 6. In the first step of the analysis, only the effect of organizational culture on job satisfaction was examined; in the second step, values were added to the analysis; in the third and last step, values-organizational culture variations were added to the analysis to measure the harmony. 
Table 6. Hierarchic Regression Analysis

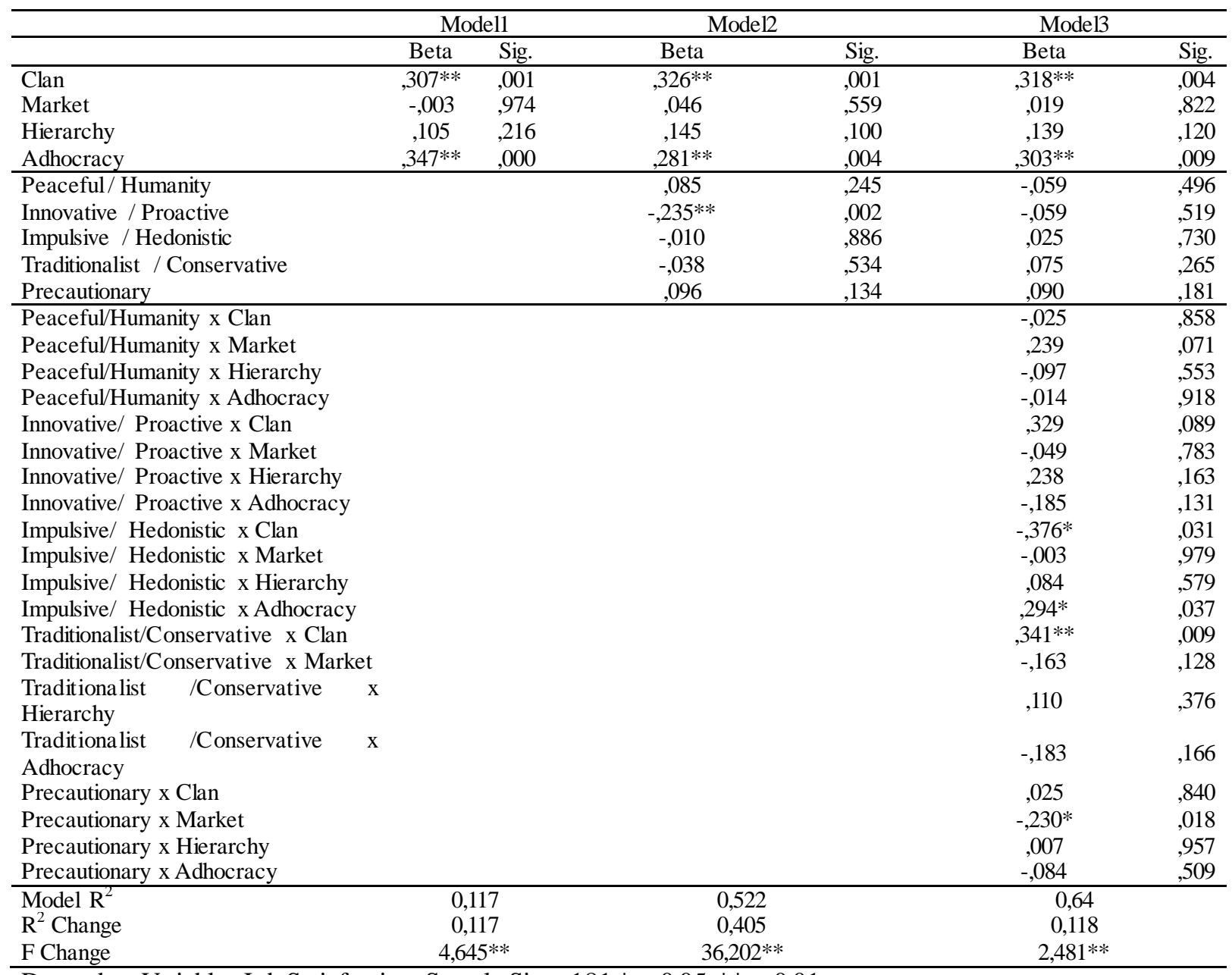

Dependent Variable: Job Satisfaction, Sample Size $=181 * \mathrm{p}<0,05, * * \mathrm{p}<0,01$

Standardized regression values are reported.

Only when the effect of organizational culture on job satisfaction is examined, clan $\left(B e t a=0.318^{* *}\right)$ and adhocracy (Beta $=0.303^{* *}$ ) cultures have a positive effect on the employee's job satisfaction. On the other hand, there is no positive or negative effect of market and hierarchical cultures. When employee values are added to the analysis, it is seen that the effect arising from values on satisfaction is only innovative/proactive, and this effect is also negative (Beta $\left.=-0,235^{* *}\right)$. In other words, employees who have innovative/proactive values regardless of other factors are more likely to have problems with job satisfaction. On the other hand, there is no positive or negative effect of peaceful/humanity, impulsive/hedonistic, traditionalist/conservative and precautionary values.

In the third step, in order to analyze the effect of the harmony between value and organizational culture on job satisfaction, value-organizational culture variations were added to the analysis. In the resulting analysis, the variation in which employees have the highest job satisfaction has become a traditionalist/conservative $\mathrm{x}$ clan. In other words, when a traditionalist/conservative employee works where the clan culture dominates, it is predicted that job satisfaction is the highest $\left(B e t a=0.341^{* *}\right)$. The second highest variation is impulsive/hedonistic $\mathrm{x}$ adhocracy (Beta $\left.=0.294^{*}\right)$. Two cultures with the most negative effects on job satisfaction are impulsive/hedonistic $\mathrm{x}$ clan $\left(\mathrm{Beta}=-0,376^{*}\right)$ and precautionary $\mathrm{x}$ market (Beta $\left.=-0,230^{*}\right)$. In other words, it can easily be said that an employee with impulsive/hedonistic values will be unhappy in a clan culture, and a precautionary employee will be unhappy in a market culture. All the other variations between value and organization culture has no significant effect on job satisfaction.

\section{Results and Discussion}

This research, designed to examine the effect of the harmony between organizational culture and individual values on job satisfaction, provides tangible results that should be taken into account, in both human resource policies of 
organizations and workplace preferences of employees. Compared to previous research, it is seen that similar results were obtained. In general, positive research results (Tsai, 2011: Jacobs \& Roodt, 2008; Amos \& Weathington, 2008; Nystrom, 1993; Din \& Ghetany, 2016; Habib, et al., 2014; Vukonjanski \& Nikolic, 2013; MacIntosh \& Doherty, 2010; Tzeng, Ketefian \& Redman, 2002) between organizational culture and job satisfaction were supported.

Moreover, the results of studies on the classification of organizational culture in this study were also supported. For example, the positive effects of the clan and adhocracy culture types on job satisfaction revealed by the research results of Lund (2013) and İşcan \& Timuoğlu (2007) were supported by the results of this research. Clan and adhocracy culture increases job satisfaction. On the other hand, the results of Yılmaz \& Dilmaç (2011) were only partially supported by this study. Yilmaz \& Dilmaç's finding that values predict job satisfaction without any grouping is also observed in relation to group satisfaction and job satisfaction as a result of factor analysis within the findings of this research. Values predict job satisfaction according to different combination groupings.

On the other hand, according to the results of this research, the two most negative effects on job satisfaction are impulsive/hedonistic-clan culture and precautionary values-market culture. In other words, it can be said that an employee with impulsive/hedonistic values will be unhappy in a clan culture, and a precautionary employee will be unhappy in a market culture.

Within the framework of results discussed above when the hypotheses formulated for the study were evaluated, it can be declared that the hypotheses were partially supported in respect of the findings. $\mathrm{H}_{1}$ that hypothesized the harmony between organizational culture and individual values has a significant effect on job satisfaction were partially supported. We found that only the harmony between clan culture and traditionalist/conservative value and the harmony between adhocracy culture and impulsive/hedonistic value affects positively and significantly job satisfaction. Moreover, we revealed that only the harmony between clan culture and impulsive/hedonistic value and market culture and precautionary value affects negatively and significantly job satisfaction. $\mathrm{H}_{2}$, hypothesizing a significant effect of types of organizational culture on job satisfaction is also partially supported. We found that only clan and adhocracy culture affect positively and significantly job satisfaction while there is no effect of market and hierarchical culture on job satisfaction. Lastly, $\mathrm{H}_{3}$ that hypothesized employees' values have a significant effect on job satisfaction is also partially supported. We revealed that only innovative/proactive value affects negatively and significantly job satisfaction while peaceful/humanity, impulsive/hedonistic, traditionalist/conservative and precautionary values have no effect on job satisfaction.

\section{Implications of the Study}

When the theoretical contribution of this study is evaluated, it can be determined that the harmony observed between different organizational culture types and values has significant effects on job satisfaction. In this context, it can be predicted whether or not job satisfaction is positive when it is known which corporation culture is compatible with which values. Businesses can seek to create a harmonious organizational culture according to these findings. The finding that especially clan and adhocracy organizational culture types increase job satisfaction should attract the attention of executives. Employees working for a service sector, especially in hospitals, agree to work in organizations where individual initiatives and risk taking are more dominant, and are more likely to prefer organizations that are more interested in providing for their needs, including a more flexible and creative work environment. This harmony has a significant impact on job satisfaction. Organizations that want to improve the job satisfaction level of their employees should try to establish clan and adhocracy cultures, in accordance with the results of the research. They may employ individuals with traditionalist/conservative and impulsive/hedonistic values. This can be achieved by retaining employees. Employees who stay with an organization tend to become more compatible with the organization, and are competitive and qualified employees.

\section{Limitations and Directions for Future Research}

Although all possible efforts have been made, some of the limitations of scientific work have also emerged in this study. First of all, although it is desirable to reach all employees by means of the full census sampling method, adequate and complete returns were not obtained from all of the hospital employees who formed the sample of the study. This was due to varied shifts, flexible work, and the intensity of the work. Therefore, in the subsequent researches, it is important to increase the number of samples. On the other hand, the fact that the study is carried out in a single organization and in one country lowers the generalizability of the study results. A comparative assessment of different organizations and countries may be the subject of future research. This study also examined the organizational culture using the instrument developed by Cameron and Quinn (2011), thus future studies can consider using other recent instruments developed by other authors such as Tsui, Wang and 
Win (2006). Finally, there can be a great number of behavioral variables other than job satisfaction affected by organizational culture and values. Since these variables were not considered in this study, various variables such as organizational commitment, job commitment, intention to leave, organizational identification, etc. can be taken into account in future research.

\section{References}

Ahamed, M., \& Mahmood, R. (2015). Impact of organizational culture on job satisfaction: A study on Banglalion Communication Ltd., Bangladesh. European Journal of Business and Management, 7(10), 160-174.

Amos, E. A., \& Weathington, B. L. (2008). An analysis of the relation between employee-organisation value congruence and employee attitudes. The Journal of Psychology, 142(6), 615-631. https://doi.org/10.3200/JRLP.142.6.615-632

Bellou, V. (2010). Organizational culture as a predictor of job satisfaction: the role of gender and age. Career Development International, 15(1), 4-19. https://doi.org/10.1108/13620431011020862

Biswas, W. (2015). Impact of organizational culture on job satisfaction and corporate performance. Journal of Research in Humanities and Social Sciences, 3(8), 14-16.

Bogdanowicz, M. (2014). Organizational culture as a source of competitive advantage - case study of a telecommunication company in Poland. International Journal of Contemporary Management, 13(3), 53-66.

Çalışkur, A. (2014). Tüketicilerin dayanıklı tüketim maddesi satın alma değer boyutları ve tüketicilerin çalışma ve öğrenci olma durumları üzerine bir araştırma. EKEV Akademi Dergisi, 60, 55-72.

Cameron, K. S., \& Quinn R. E. (2011). Diagnosing and Changing Organizational Culture: Based on the Competing Values Framework, USA: John Wiley \& Sons.

Cavanagh, G. F., \& McGovern, A. F. (1998). Ethical in the Modern Corporation. New Jersey: Prentice-Hall Inc.

Çavuşoğlu, S., \& Köse, S. (2016). Örgüt kültürünün örgütsel sessizlik davranışına etkisi Dokuz Eylül Üniversitesi Sosyal Bilimler Enstitüsü Dergisi, 18(1), 115-146.

Cekuls, A. (2015). Leadership values in transformation of organizational culture to implement competitive intelligence management: The trust building through organizational culture. European Integration Studies, 9, 244-256. https://doi.org/10.5755/j01.eis.0.9.12811

Connor, E. P., \& Becker, B. W. (2002). Values and the organization: suggestions for research. Academy of Management, 18(3), 550-561. https://doi.org/10.2307/255684

Daft, L. R. (2015). Understanding the Theory and Design of Organizations, (10th ed.), (Özmen, Ö.N.T., Gürbüz, S. Trans.) Ankara: Nobel Yayıncılık.

Devrani, K. T. (2010). Kişisel değerlerin kuramsal yapısı ve pazarlamadaki uygulamaları. Eskişehir Osmangazi Üniversitesi Ï̈BF Dergisi, 5(1), 49-70.

Din, H. F., \& Ghetany, H. E. (2016). The relationship between organisational culture and job satisfaction: an international perspective. International Conference on Management, Leadership \& Governance, 101-109.

Erdem, R. (2007). Örgüt kültürü tipleri ile örgütsel bağl1lık arasındaki ilişki: Elaziğ il merkezindeki hastaneler üzerinde bir çalışma. Eskişehir Osmangazi Üniversitesi İ̈BF Dergisi, 2(2), 63-79.

Erdoğan, İ. (2007). İşletmelerde Davranış (7th ed.), İstanbul: MİAD Yönetim Yayınları Dizisi.

Fleury, M. T. L. (2009). Organizational culture and the renewal of competence. BAR, Curitiba, 6(1), 1-14. https://doi.org/10.1590/s1807-76922009000100002

Habib, S., Aslam, S., Hussain, A., Yasmeen, S., \& Ibrahim, M. (2014). The impact of organizational culture on job satisfaction, employees' commitment and turnover intention. Advances in Economics and Business, 2(6), 215-222.

Hofstede, G. (2001). Culture's Consequences: Comparing Values, Behaviors, Institutions, and Organizations Across Nations (2nd ed.), Beverly Hills, CA: Sage.

İşcan, Ö. F., \& Timuroğlu, M. K. (2007). Örgüt kültürünün iş tatmini üzerindeki etkisi ve bir uygulama. Atatürk Üniversitesi İktisadi ve İdari Bilimler Dergisi, 21(1), 119-135.

Jacobs, E., \& Roodt, G. (2008). Organizational culture of hospitals to predict turnover intentions of professional nurses. Journal of Interdisciplinary Health Sciences, 13(1), 63-78. https://doi.org/10.4102/hsag.v13i1.258 
Johonson, J. J., \& Mclynte, C. L. (1998). Organizational culture and climate correlates of job satisfaction. Psychological Reports, 82(3), 843-850. https://doi.org/10.2466/pr0.1998.82.3.843

Kane-Urrabazo, C. (2006). Management's role in shaping organizational culture. Journal of Nursing Management, 14, 188-194. https://doi.org/10.1111/j.1365-2934.2006.00590.x

Kaoa, C. Y., Tsaur, S. H., \& Wub, T. C. (2016). Organizational culture on customer delight in the hospitality industry. International Journal of Hospitality Management, 56, 98-108. https://doi.org/10.1016/j.ijhm.2016.05.001

Kılıç, K. C. (2010). Bireysel ve örgütsel değerler arasındaki uyumun çalışanların iş davranışlarına etkileri üzerine ampirik bir çalışma. Ç.Ü. Sosyal Bilimler Enstitüsü Dergisi, 19(1), 20-35.

Knoppen, D., \& Saris, W. (2009). Do we have to combine values in the schwartz' human values scale? A comment on the davidov studies. Survey Research Methods, 3(2), 91-103.

Körner, M., Wirtz, M. A., Bengel, J., \& Göritz, A. S. (2015). Relationship of organizational culture, teamwork and job satisfaction in interprofessional teams. BMC Health Services Research, 15, 243-255. https://doi.org/10.1186/s12913-015-0888-y

Landekić, M., Šporčić, M., Martinić, I., \& Bakarić, M. (2015). Influence of organizational culture on firm efficiency: competing values framework in croatian forestry. Scandinavian Journal of Forest Research, 30(7), 624-636. https://doi.org/10.1080/02827581.2015.1046480

Lilleoja, L., \& Saris, W. E. (2014). Testing a new operationalization of the basic values on estonian- and russian-speaking subpopulations in estonia. Social Indicators Research, 116(1), 153-172. https://doi.org/10.1007/s11205-013-0272-4

Locke, E. A. (1976). The Nature and Causes of Job Satisfaction, In M.D. Dunnette (Ed.), Handbook of industrial and organizational psychology, 1297-1349, Chicago: Rand McNally.

Lund, B. D. (2003). Organizational culture and job satisfaction. Journal of Business \& Industrial Marketing, 18(3), 219-236. https://doi.org/10.1108/0885862031047313

MacIntosh, E. W., \& Doherty, A. (2010). The Influence of organizational culture on job satisfaction and intention to leave. Sport Management Review, 13(2), 106-117. https://doi.org/10.1016/j.smr.2009.04.006

Martins, H., \& Proença, T. (2011). "Minnesota Satisfaction Questionnaire - Psychometric properties and validation in a population of Portuguese Hospital Workers", Investigação e Intervenção em Recursos Humanos 2011 - gestão para a cidadania Escola Superior de Estudos Industriais e de Gestão do Instituto Politécnico do Porto 27-28 October.

Muafi, M., (2009). The effects of alignment competitive strategy, culture and role behavior on organizational performance in service firms. International Journal of Organizational Innovation, 2(1), 106-134.

Nam, Y. M., \& Kim, H. S. (2016). A study on the effect of industry organizational culture on job attitude of organizational employees - comparison between the semiconductor and the automobile industries. Procedia Computer Science, 91, 581-590. https://doi.org/10.1016/j.procs.2016.07.149

Naqshbandi, M. M., \& Kaur, S. (2011). A study of organizational citizenship behaviours, organizational structures and open innovation. International Journal of Business and Social Science, 2(6), 182-193.

Naqshbandi, M. M., Kaur, S., \& Ma, P. (2015a). What organizational culture types enable and retard open innovation? Quality \& Quantity, 49(5), 2123-2144. https://doi.org/10.1007/s11135-014-0097-5

Naqshbandi, M. M., Kaur, S., Sehgal, R., \& Subramaniam, I. D. (2015b). Organizational culture profile of Malaysian high-tech industries. Asia-Pacific Journal of Business Administration, 7(1), 2-19. https://doi.org/10.1108/APJBA-08-2013-0088

Naqshbandi, M. M., Singh, S. K. G., \& Ma, P. (2016). The link between organisational citizenship behaviours and open innovation: A case of Malaysian high-tech sector. IIMB Management Review, 28(4), 200-211. https://doi.org/10.1016/j.iimb.2016.08.008

Newton, J. C., \& Mazur, A. K. (2016). Value congruence and job-related attitudes in a nonprofit organization: a competing values approach. The International Journal of Human Resource Management, 27(10), 1013-1033. https://doi.org/10.1080/09585192.2015.1053962

Nystrom P. C. (1993). Organizational cultures, strategies, and commitments in health care organizations. Health Care Management Review, 18(1), 43-49. https://doi.org/10.1097/00004010-199301810-00005 
O'Riordan, J. (2015). Organizational culture and the public service. IPA Research Paper, No: 16, Retrieved February 3, 2017 from https://www.ipa.ie/pdf/Organisational_Culture.pdf

Odom, R. Y., Boxx, W. R., \& Dunn, M. G. (1990). Organizational cultures, commitment, satisfaction, and cohesion. Public Productivity \& Management Review, 14(2), 157-169. https://doi.org/10.2307/3380963

Olasupo, M. O. (2011). Relationship between organizational culture, leadership style and job satisfaction in a nigerian manufacturing organization. IFE Psychological, 19(1). https://doi.org/10.4314/ifep.v19i1.64595

Öz, M., Kaya, F., \& Ciftci, I. (2015). Evaluating the organizational culture types of the 5 -star hotel's in Istanbul in terms of the Cameron \& Quinn competing values model. Journal of Yasar University, 10(40), 6684-6691. https://doi.org/10.19168/jyu.92229

Özcan, H. U. (2012). Birey-örgüt değerleri arasındaki uyumun örgütle özdeşleşme ile ilişkisi. Türk Psikoloji Yazıları, 15(29), 25-39.

Özgener, Ş. (2004). Işs Ahlakının Temelleri Yönetsel Bir Yaklaşım. Ankara: Nobel Yayıncılık.

Riggio, E. R. (2014). Introduction to Industrial/Organizational Psychology (6th ed.), (B. Özkara, Trans.). Ankara: Nobel Yayınc1lik.

Rızaoğlu, B., \& Ayyıldız, T. (2008). Konaklama işletmelerinde örgüt kültürü ve iş tatmini: Didim örneği. Anatolia: Turizm Araştirmalart Dergisi, 19(1), 7-20.

Robbins, P. S., \& Judge, A. T. (2013), Organizational Behaviour, (14th. ed.). (I.Erdem \& B. Aydıntan, Trans.). Ankara: Nobel Yayıncilik.

Robbins, P. S., \& Judge, A. T. (2014). Organizational Behaviour, (15th ed.). USA: Prentice Hall.

Saari, M. L., \& Judge, T. A. (2004). Employee attitudes and job satisfaction. Human Resources Management, 43(4), 395-407. https://doi.org/10.1002/hrm.20032

Schein, E. H. (1984). Coming to a new awareness of organizational culture. Sloan Management Review, 25(2), 3-16.

Schermerhorn, R. J., Jr. Hunt, Osborn, R. N., \& Uhl-Bien, M. (2010). Organizational Behaviour, (11th ed.). USA: John Wiley \& Sons.

Schwartz, S. H. (1992). Universals in the content and structure of values: Theoretical advances and empirical tests in 20 countries. Advances in Experimental Social Psychology, 25, 1-65. https://doi.org/10.1016/S0065-2601(08)60281-6

Schwartz, S. H. (1994), Are there universal aspects in the structure and contents of human values?. Journal of Social Issues, 50(4), 19-45. https://doi.org/10.1111/j.1540-4560.1994.tb01196.x

Schwartz, S. H. (2012). An overview of the schwartz theory of basic values. Online Readings in Psychology and Culture, 2(1). https://doi.org/10.9707/2307-0919.1116

Schwartz, S. H. (2017). A proposal for measuring value orientations across nations. Retrieved Fevruary 3, 2017, from

https://www.europeansocialsurvey.org/docs/methodology/core_ess_questionnaire/ESS_core_questionnaire_ human_values.pdf

Şendoğdu, A. A., Özata, M., \& Esra, Ç. (2014). KOBI’lerde kurum kültürünün yönetim desteği boyutu ile işgörenlerin iş tatmini ilişkisi üzerine bir saha araştırması. Atatürk Üniversitesi İktisadi ve İdari Bilimler Dergisi, 28(1), 215-229.

Şişman, M. (2002). Örgütler ve Kültürler, Ankara: Pegema Yayıncılık.

To vey, E. J., \& Adams, A. E. (1999). The changing nature of nurses' job satisfaction: an exploration of sources of satisfaction in the 1990s. Journal of Advanced Nursing, 30(1), 150-158. https://doi.org/10.1046/j.1365-2648.1999.01059.x

Tsai, Y. (2011). Relationship between organizational culture, leadership behavior and job satisfaction. BMC Health Services Research, 11, 98. https://doi.org/10.1186/1472-6963-11-98

Tsui, A. S., Wang, H., \& Xin, K. R. (2006). Organizational culture in China: an analysis of culture dimensions and culture types. Management and Organization Review, 2(3), 345-376. https://doi.org/10.1111/j.1740-8784.2006.00050.x

Türk, M. S. (2007). Örgüt Kültürü ve İş Tatmini, Ankara: Gazi Kitapevi. 
Tzeng, H. M., Ketefian, S., \& Redman, R. W. (2002). Relationship of nurses' assessment of organizational culture, job satisfaction, and patient satisfaction with nursing care. International Journal of Nursing Studies, 39(1), 79-84. https://doi.org/10.1016/S0020-7489(00)00121-8

Vukonjanski, J., \& Nikolić, M. (2013). Organizational culture and job satisfaction-the effects of company’s ownership structure. Journal of Engineering Management and Competitiveness, 3(2), 41-49.

Wagner, A. J., \& Hollenbeck, J. R. (2010). Organizational Behavior: Securing Competitive Advantage, New York: Routledge.

Yılmaz, E., \& Dilmaç, B. (2011). An investigation of teachers values and job staidfaction. Elementary Education Online, 10(1), 302-310.

\section{Copyrights}

Copyright for this article is retained by the author(s), with first publication rights granted to the journal.

This is an open-access article distributed under the terms and conditions of the Creative Commons Attribution license (http://creativecommons.org/licenses/by/4.0/). 